\title{
The Historical Lack of Capital Accumulation in Iran's Agricultural Part
}

\author{
${ }^{1}$ Hossein Askaripour Lahiji, ${ }^{2}$ Ali Akbar Dadashpour, ${ }^{3}$ Farshad Sameni Keivani \\ ${ }^{I,}$ Department of Accounting, Islamic Azad University, Lahijan Branch, Iran. \\ ${ }^{2}$ Department of Management, Islamic Azad University, Rasht Branch, Iran. \\ ${ }^{3}$ Department of Accounting, Islamic Azad University, Roudsar and Amlash Branch, Iran
}

\begin{abstract}
The increasing amount of income due to the discovery of oil in Iran has caused a gap between the production and need of agricultural products, causing the increase in the import of agricultural products in Iran's economy. The existing gap caused a drastic increase in the prices, and since the growth of agricultural products needed Infrastructure investment, it has been tried to control the increase in the prices with an increase in the import rate. So capital accumulation has not been done to the required rate and the production in agriculture has not increased to the expected rate. The share of workers in the agricultural sector of Iran has faced a decrease since 1980. This is while in the international level, agriculture for the growth of economy, decrease of poverty, food security, and the stability of environment is of high importance. A general investment can reduce risks in the agriculture and increase efficiency in private sectors, so the motives of farmers for investment will be increased.
\end{abstract}

Keywords: agricultural sectors efficiency, Iranian agricultural accumulated capital .

\section{Introduction}

By 1939, the agriculture of Iran provided the food and industry needs-especially the textile sector-and with export of part of its production supplied the required foreign exchange for investment. The only goods imported from foreign countries were tea and sugar. After that the rate of import has increased very fast. Before the land reform movement due to the per capita income of 10 to 15 dollars per year, the import and export of agricultural products were the same and even the export rate was sometimes more [1].

When in 1972 the per capita income reached 500 dollars, again the $4 \%$ growth in agriculture sector did not meet the increase in needs [2]. Since 1974 due to the 20 billion dollars income of oil, the buying power of people increased to $10 \%$, but the production just increased as $5 \%$. This gap caused a drastic increase in the prices and because the growth of agricultural products needed infrastructure investment, the government tried to control the prices with an increase in the import rate [3,4]. Because of this the dependence in the agriculture sector increased. Either before the Islamic revolution and after it, the accumulation of capital has not been performed in a sufficient way, or agricultural production has not increased as it must $[5,6]$.

\section{The Data and Trend of Active Economic Population}

Agricultural products which are forced to be imported to Iran are: wheat, barley, vegetable oil, feed, rice, sugar, soya, corn, and oil seeds for which in some years even up to 10 billion dollars have been spent [7]. It is conclude that the problem in agriculture sector is the historical lack of investment in it.

In one way the excessive price of food caused the society to face malnutrition. More than $50 \%$ of the lower classes of society's expenses are spent on food [1]. More than $40 \%$ of rural and more than $30 \%$ of urban families face the food shortage threat. This is while the standard in the world is just about $7 \%$. The ratio of nonfood expenses to food ones is one of the determining indexes of the welfares of the families. The higher this index is, the higher the welfare of the family's .This ratio for Iran's economy was 3.4 in 2009. This ratio, however, for developed countries is between 4 to 5 and for developing countries is between 3 to $4[8,9]$. The following tables shows the data resulting is given the explanations above:

Table 1 shows that the share of farmers in Iran's agriculture has decreased since 2001. This decreased from 39\% in year 1980 to $22 \%$ in 2010 .

Table 1: the active population in Iran's agriculture sector and its share of the total economy

\begin{tabular}{|c|c|c|c|c|c|c|c|c|}
\hline \multicolumn{2}{|c|}{ description } & \multicolumn{4}{|c|}{$\begin{array}{l}\text { The active population in agriculture } \\
\text { (thousand) }\end{array}$} & \multicolumn{3}{|c|}{$\begin{array}{l}\text { The share of agriculture of the total } \\
\text { active economical population (percent) }\end{array}$} \\
\hline Year & 1980 & 1990 & 2000 & 2010 & 1980 & 1990 & 2000 & 2010 \\
\hline Iran & 4260 & 5040 & 5761 & 6553 & 39 & 32 & 27 & 22 \\
\hline
\end{tabular}


According to table 2 the per capita income of workers of the existing capital has faced a decrease in the last decade.

Table 2: the total stock and the per capita income of agriculture

\begin{tabular}{|l|c|c|c|c|c|c|c|c|}
\hline Description & \multicolumn{3}{l|}{ The stock of agriculture capital (million dollars of 2005) } & \multicolumn{2}{l}{$\begin{array}{l}\text { The per capita income of each } \\
\text { worker (fixed dollar of } 2005 \\
\text { America) }\end{array}$} \\
\hline Year & 1980 & 1990 & 2000 & 2010 & 1980 & 1990 & 2000 & 2010 \\
\hline Iran & 46137 & 67144 & 74309 & 82643 & 10830 & 13322 & 12899 & 12841 \\
\hline
\end{tabular}

Table 3: the total amount of the government expenses in the agriculture sector and its share of the total expenses

\begin{tabular}{|c|c|c|c|c|c|c|c|c|}
\hline & description & \multicolumn{4}{|c|}{$\begin{array}{l}\text { The total governmental expenses in agriculture (million } \\
\text { dollars the fixed buying power 2005) }\end{array}$} & \multicolumn{3}{|c|}{$\begin{array}{l}\text { The share of agriculture of the } \\
\text { total expenses (percent) }\end{array}$} \\
\hline Year & & \begin{tabular}{|l|l|}
80 & 1990
\end{tabular} & 2000 & 2010 & 1980 & \begin{tabular}{l|l} 
& 1990
\end{tabular} & 2000 & 2010 \\
\hline Iran & & 2324 & 1947 & 5985 & 3.4 & 3.4 & 1.9 & 3.1 \\
\hline
\end{tabular}

Around $12 \%$ of our GPD is due to agriculture. But table 3 shows that its share of governmental expenses is just around $3 \%$.

Table 4: the governmental expenses on the per capita income of agricultural worker and the orientation index.

\begin{tabular}{|c|c|c|c|c|c|c|c|c|}
\hline $\begin{array}{l}\text { descripti } \\
\text { on }\end{array}$ & \multicolumn{4}{|c|}{$\begin{array}{l}\text { the per capita income of agriculture(the fixed buying power } \\
\text { dollar of 2005) }\end{array}$} & \multicolumn{3}{|c|}{ orientation index (percent) } & \\
\hline year & 1980 & 1990 & 2000 & 2010 & 1980 & 1990 & 2000 & 2010 \\
\hline Iran & 629 & 442 & 329 & 917 & 0.20 & 0.18 & 0.14 & 0.30 \\
\hline
\end{tabular}

The orientation index AO1 which is defined as the ratio of the agriculture in governmental expenses to the share of agricultural sector in the total amount of GPD and reflexes the importance of the economic sector based on table 4 is about 0.2 to 0.3 . Also the information in table 5 shows the governmental expenses of Iran in agricultural research and development. The share of these expenses does not reach $1 \%$ even.

Table 5: governmental expenses in agricultural research and development

\begin{tabular}{|l|c|c|c|c|c|c|c|c|}
\cline { 2 - 9 } \multicolumn{1}{l|}{ Description } & \multicolumn{3}{l|}{ Total (million dollar the fixed buying power of } & \multicolumn{3}{l|}{ As the share of agricultural GPD (percent) } \\
\hline year & 1980 & 1990 & 2000 & 2010 & 1980 & 1990 & 2000 & 2010 \\
\hline Iran & - & - & 508 & 559 & - & - & 0.76 & 0.82 \\
\hline
\end{tabular}

\section{Discussion}

Agriculture has a noticeable position worldwide because of its role in economic growth, decreasing the amount of poverty, food security, and the stability of environment. Today, the priority of most countries for future prospects is agriculture. Even a country like Japan which does not have enough land for farming is investing in this sector [10]. Investing in agriculture is one of the most efficient strategies for decreasing poverty and improving Sustainable Development. Parts of the world in which capital per capita of agriculture of each worker and the governmental expenses for each worker has been steady or decreased are the points of poverty and starvation today [11]. The increasing need for agricultural products in the future decades will put a lot of pressure on natural resources. The resources which have been increasing in most areas are now decreasing. Investing for protecting natural resources and reaching sustainable development is necessary. Removing starvation in a fixed way requires the increase in investment in agriculture and above all the improvement in the quality of investment.

\section{Conclusion}

Farmers cannot invest in the lack of appropriate motives and general goods. The agricultural production is seasonal usually, and is vulnerable to natural phenomena such as drought, loss, and illnesses. The agricultural production is widespread in terms of geographical locations and most of the agricultural products are large, and vulnerable to spoil. Investment in agriculture is a risky job and depends on village infrastructure, the good distribution of production mangers, convertible industries, organization making the market clear, and price indexes. Agricultural research and infrastructure affairs of the market are the most important kind of governmental investment in the agricultural sector. Appropriate investment can reduce the amount of risk and increase the efficiency of the private sectors; thus, increasing the motivation of farmers for investment. 


\section{References}

[1] M Katuzian, the political economy of Iran, translated by mohammad reza nafisi and kambiz azizi, markaz publications, Tehran,1994.

[2] R Badiee, profound geography of Iran, eghbal publications, $3^{\text {rd }}$ volume, Tehran 1983.

[3] Johnson, H.G., Economic policies toward less developed countries. 1967: Brookings institution Washington, DC.

[4] Glover, D. and K. Kusterer, Small farmers, big business: contract farming and rural development. 1990: St. Martin's Press.

[5] F Tari, , resistance economy and its factors $1^{\text {st }}$ edition, the center for research of Iran's legislation, Tehran,2012.

[6] Sarris, A., The role of agriculture in economic development and poverty reduction. The World Bank, Washington, DC, 2003.

[7] A Dadashpour, the study of the impact of general goods on the price elasticity of all agricultural sectors of Iran, M.A. thesis, university of Isfahan,2012.

[8] A Nouri, the profile of guilan's economy, $1^{\text {st }}$ edition, sotudeh publications, rasht, . 26-27, 2011.

[9] A Yavari, knowing the traditional agriculture of Iran, the center for translation and publishing books, Tehran,1980.

[10] R Eftekhari, the economy of Iran, the organization of trade studies and research, Tehran, 1992.

[11] Nakamura, J.I., Agricultural production and the economic development of Japan, 1873-1922. 1966: Cambridge Univ Press. 